\title{
Template Synthesis and X-Ray Structure of the First Cobalt(II) Glyoximate Clathrochelate with Terminal Formyl Groups
}

\author{
Genrikh E. Zelinskii, ${ }^{a}$ Alexander S. Belov, ${ }^{a}$ Anna V. Vologzhanina, ${ }^{a}$ \\ Valentin V. Novikov, ${ }^{a}$ Alexander A. Pavlov, ${ }^{a}$ Yan V. Zubavichus, ${ }^{\text {b }}$ \\ and Yan Z. Voloshin"a,c@
}

\begin{abstract}
aNesmeyanov Institute of Organoelement Compounds of the Russian Academy of Sciences, 119991 Moscow, Russia
'National Research Center "Kurchatov Institute”, 123182 Moscow, Russia

'I.M. Gubkin Russian State University of Oil and Gas, 119991 Moscow, Russia

@Corresponding authorE-mail:voloshin@ineos.ac.ru
\end{abstract}

Cobalt(II) tris-glyoximate clathrochelate $\mathrm{CoGm}{ }_{3}\left(\mathrm{~B}_{4}-\mathrm{C}_{6} \mathrm{H}_{4} \mathrm{CHO}\right)_{2}$ with terminal reactive formyl group was obtained in moderate yield using direct template cross-linking of three molecules of glyoxime with 4-formylphenylboronic acid on a cobalt(II) ion as a matrix. Its molecular structure has been determined using single-crystal X-ray diffraction experiment.

Keywords: Macrocyclic compounds, clathrochelates, template condensation.

\section{Темплатный синтез и структура первого глиоксиматного клатрохелата кобальта(II) с терминальными формильными группами}

\author{
Г. Е. Зелинский, ${ }^{a}$ А. С. Белов, ${ }^{a}$ А. В. Вологжанина, ${ }^{a}$ В. В. Новиков, ${ }^{a}$ А. А. Павлов, \\ Я. В. Зубавичус, ${ }^{\text {b }}$ Я. З. Волошин ${ }^{\text {a,c@ }}$
}

${ }^{a}$ Институт элементоорганических соединений им. А. Н. Несмеянова, 119991 Москва, Россия

${ }^{\mathrm{b}}$ Национальный исследовательский центтр «Курчатовский институт», 123182 Москва, Россия

'Российский государственный университет нефти и газа им. И.М. Губкина, 119991 Москва, Россия

${ }^{\circledR}$ E-mail:voloshin@ineos.ac.ru

\begin{abstract}
Трис-глиоксиматный клатрохелат кобальта(II) с терминальными реакционноспособными формильными группами был получен прямой темплатной сшивкой трех молекул глиоксима 4-формилфенилборной кислотой на ионе кобальта(II) как матрице. Молекулярная структура соединения была установлена методом РСА.
\end{abstract}

Ключевые слова: Макроциклические соединения, клатрохелаты, темплатная конденсация.

Mono- and binuclear clathrochelate complexes with functionalizing apical and ribbed substituents containing terminal donor groups such as pyridine, carboxylic or cyano groups as prospective rigid and robust macrobicyclic ligands towards transition and main groups metal ions are reported in ${ }^{[1-6]}$ allowing to obtain a wide range of nanosized heterometallic clathrochelate-based metallomacrocycles, coordination polymers and cages. On the other hand, the formyl-terminated clathrochelates seems to be suitable ligand synthones or monomers for the design and synthesis of the imine coordination cages and coordination polymers and their amine derivatives as well. Moreover, the reactivity of their terminal formyl groups can be used for preparation of cage complexes with vector substituents, allowing their target delivery for a given biosystem. 
Very recently, the corresponding mononuclear tris-glyoximate iron(II) clathrochelates ${ }^{[7]}$ and their aliphatic tris-dioximate analogs, ${ }^{[8]}$ as well as the homobinuclear manganese(II) and cobalt(II) 4-formylphenylboron-capped clathrochelates ${ }^{[8]}$ have been prepared and X-ray structurally characterized. Among them, the binuclear cage complexes are reported in ${ }^{[4]}$ to be prospective for production of magnetic materials: for example, the binuclear cobalt(II) clathrochelates with pendant carboxylic acid groups showed high-spin state of their encapsulated cobalt(II) ions. In this work we report the synthesis and X-ray structure of the first mononuclear macrobicyclic cobalt(II) trisglyoximate with terminal formyl groups.

Like its iron(II)-encapsulating analog ${ }^{[7]}$ 4-formylphenylboron-capped cobalt(II) clathrochelate $\mathrm{CoGm}_{3}$ (B4$\left.\mathrm{C}_{6} \mathrm{H}_{4} \mathrm{CHO}\right)_{2}$ was obtained in moderate yield under vigorous reaction conditions (in boiling nitromethane as a solvent) by Scheme 1 using direct template cross-linking of three molecules of glyoxime with 4-formylphenylboronic acid on a cobalt(II) ion as a matrix. ${ }^{[9]}$ Despite that an iron(II) ion is known in literature to be the most efficient template for such self-assembly than a cobalt(II) ion, ${ }^{[10]}$ the yields of these clathrochelate derivatives of the same caging ligand were almost the same (65vs. $62 \%$, respectively).

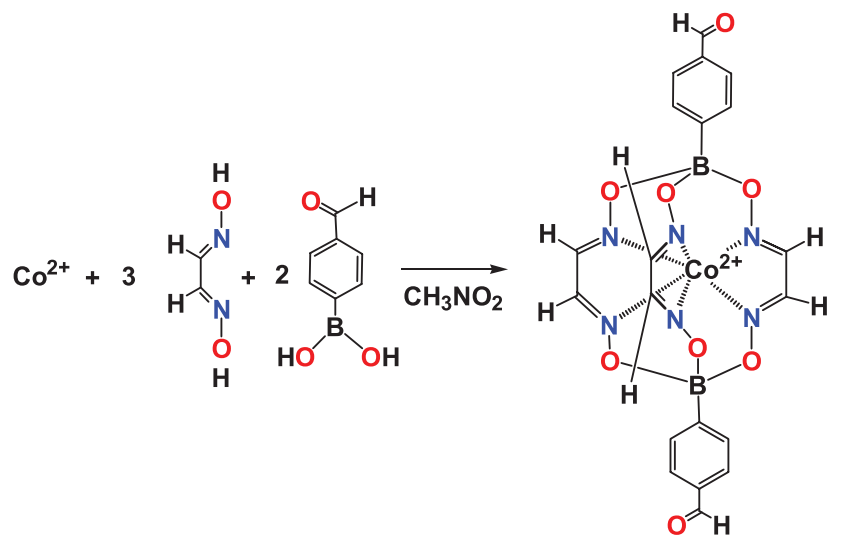

Scheme 1.

The complex obtained was characterized using elemental analysis, MALDI-TOF mass spectrometry, IR, ${ }^{1} \mathrm{H}$ NMR spectroscopy, and by single-crystal X-ray diffraction. ${ }^{[9]}$

The most intense peak in the positive range of the MALDI-TOF mass spectrum of this cobalt(II) clathrochelate belongs to its molecular ion.

The obtained paramagnetic shift values were analyzed as a difference between the chemical shifts in the NMR spectra of the paramagnetic cobalt(II)- and diamagnetic iron(II)-encapsulating clathrochelate analogs. The low-spin cobalt(II) ion can give rise to both the contact and pseudocontact paramagnetic shifts due to the direct spin delocalization and the dipolar interaction, respectively. In order to fully quantitatively describe the NMR data, quantum chemical (DFT) calculations of molecular geometry and spin density distribution were carried out. ${ }^{[9]}$ According to the calculations the origin of paramagnetic shifts is different for various protons in a molecule: glyoxime protons are characterized by significant contact shifts $(\sim 90 \mathrm{ppm})$ owing its nearness to the paramagnetic cobalt(II) ion while paramagnetic shifts of

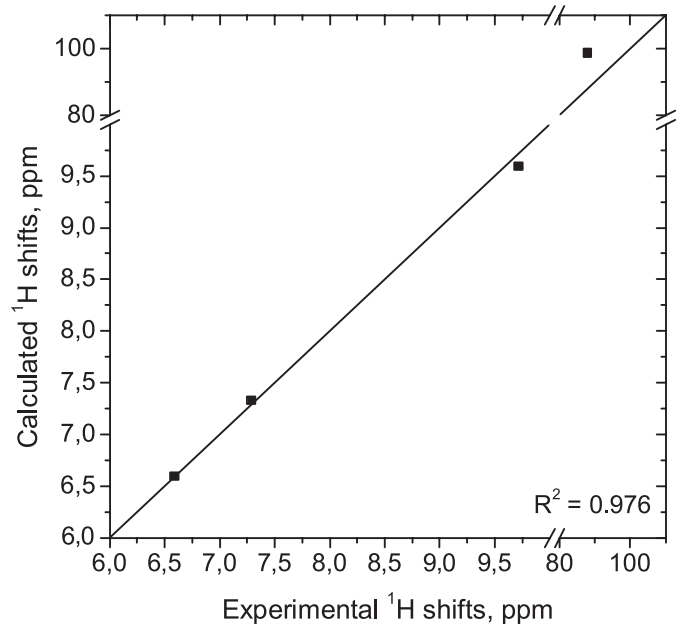

Figure 1. Correlation plot of experimental and calculated ${ }^{1} \mathrm{H}$ NMR chemical shifts.

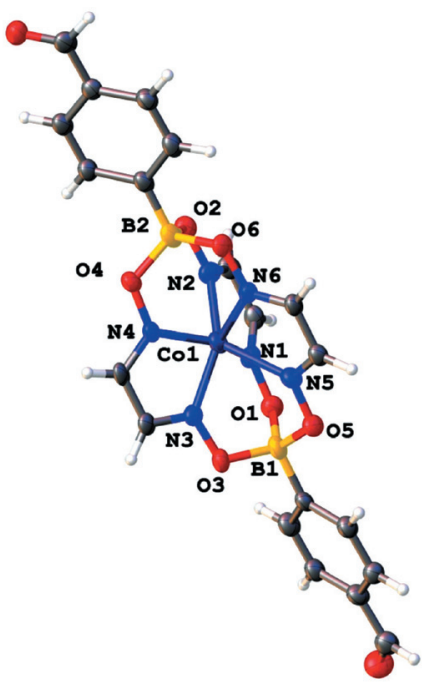

Figure 2. General view of the molecule $\mathrm{CoGm}_{3}\left(\mathrm{~B}-4-\mathrm{C}_{6} \mathrm{H}_{4} \mathrm{CHO}\right)_{2}$ in representation of atoms with thermal ellipsoids (given with $\mathrm{p}=50 \%)$.

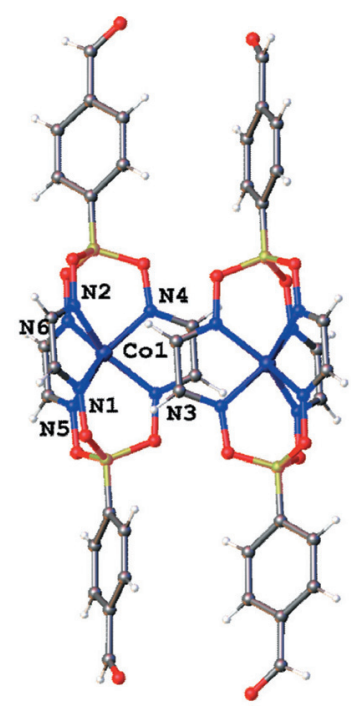

Figure 3. Formation of the $\pi$... $\pi$-bonded clathrochelate dimers in the crystal $\mathrm{CoGm}_{3}\left(\mathrm{~B} 4-\mathrm{C}_{6} \mathrm{H}_{4} \mathrm{CHO}\right)_{2} \cdot 0.5 \mathrm{CH}_{2} \mathrm{Cl}_{2}$. 
Table 1. Main geometrical parameters of the tris-glyoximate metal clathrochelates with terminal formyl groups

\begin{tabular}{lccc} 
Parameter & $\mathrm{CoGm}_{3}\left(\mathrm{~B} 4-\mathrm{C}_{6} \mathrm{H}_{4} \mathrm{CHO}\right)_{2}$ & \multicolumn{2}{c}{$\mathrm{FeGm}_{3}\left(\mathrm{~B} 3-\mathrm{C}_{6} \mathrm{H}_{4} \mathrm{CHO}\right)_{2}{ }^{[7]}$} \\
$\mathrm{M}-\mathrm{N}(1)(\AA)$ & $1.882(7)$ & Triclinic polymorph & $1.912(2)$ \\
$\mathrm{M}-\mathrm{N}(2)(\AA)$ & $1.892(6)$ & $1.920(2)$ & $1.909(6)$ \\
$\mathrm{M}-\mathrm{N}(3)(\AA)$ & $1.884(6)$ & $1.910(2)$ & $1.907(6)$ \\
$\mathrm{M}-\mathrm{N}(4)(\AA)$ & $1.871(7)$ & $1.912(2)$ & $1.909(6)$ \\
$\mathrm{M}-\mathrm{N}(5)(\AA)$ & $2.101(6)$ & $1.907(2)$ & $1.905(6)$ \\
$\mathrm{M}-\mathrm{N}(6)(\AA)$ & $2.096(6)$ & $1.920(2)$ & $1.912(7)$ \\
$\mathrm{B}-\mathrm{O}(\AA)$ & $1.495(8)-1.518(11)$ & $1.480(4)-1.511(3)$ & $1.453(11)-1.491(9)$ \\
& $a v .1 .502$ & $a v .1 .498$ & $a v .1 .475$ \\
$\mathrm{~N}-\mathrm{O}(\AA)$ & $1.368(9)-1.383(8)$ & $1.366(3)-1.371(3)$ & $1.367(8)-1.379(8)$ \\
$\mathrm{C}=\mathrm{N}(\AA)$ & $a v .1 .377$ & $a v .1 .369$ & $a v .1 .373$ \\
$\mathrm{C}-\mathrm{C}(\AA)$ & $1.270(9)-1.300(21)$ & $1.295(3)-1.308(3)$ & $1.283(9)-1.293(9)$ \\
& $a v .1 .291$ & $a v .1 .302$ & $a v .1 .288$ \\
$\mathrm{~N}=\mathrm{C}-\mathrm{C}=\mathrm{N}\left(^{\circ}\right)$ & $1.440(11)-1.446(12)$ & $1.418(4)-1.424(4)$ & $1.401(10)-1.412(10)$ \\
$\varphi\left({ }^{\circ}\right)$ & $a v .1 .444$ & $a v .1 .421$ & $a v .1 .406$ \\
$\alpha\left(^{\circ}\right)$ & $0.3(2)-0.9(9)$ & $6.6(4)-7.7(4)$ & $5.1(10)-6.8(11)$ \\
$h(\AA)$ & $a v .0 .6$ & $a v .7 .2$ & $a v .5 .9$
\end{tabular}

the apical substituents have the pseudocontact nature, due to their remoteness from the metal ion.

Good convergence $\left(\mathrm{R}^{2}=0.976\right)$ of experimental paramagnetic shifts and DFT calculated contact shifts (Figure 1) allowed us to clearly assign the signals of ${ }^{1} \mathrm{H}$ NMR spectrum. The number and positions of the signals in the solution ${ }^{1} \mathrm{H}$ NMR spectrum of the cage complex as well as the ratios of the integral intensities confirm the composition of this clathrochelate.

Molecular structure of the complex $\mathrm{CoGm}_{3}(\mathrm{~B} 4-$ $\left.\mathrm{C}_{6} \mathrm{H}_{4} \mathrm{CHO}\right)_{2}$ is shown in Figure 2; the main geometrical parameters of its clathrochelate framework as well as those for its iron(II)-encapsulating analogue $\mathrm{FeGm}_{3}\left(\mathrm{~B} 4-\mathrm{C}_{6} \mathrm{H}_{4} \mathrm{CHO}\right)_{2}$ are listed in Table 1.

Due to the rigidity of the chelate $\mathrm{N}=\mathrm{C}-\mathrm{C}=\mathrm{N}$ fragments, the bite (chelate) angles $\alpha$ and the main distances in their macrobicyclic framework persist, whereas the geometries of $M N_{6}-$ coordination polyhedra are strongly affected by the nature of an encapsulated metal ion, first of all, due to the distortion of these polyhedra around the molecular $C_{3}$-pseudoaxis the distortion angle $\varphi$ is equal to $0^{\circ}$ for a trigonal prism (TP) and to $60^{\circ}$ for a trigonal antiprism (TAP) $\}$. TAP geometry is energetically preferable for the low-spin electronic configurations $d^{6}$ and $d^{7}$, whereas in the case of the diboron-capped polyazomethine quasiaromatic tris-dioximates an encapsulation of a metal ion causes a TP distortion of this geometry due to a small Shannon radius of their capping boron atoms. As a result, the geometries of $\mathrm{FeN}_{6}$-coordination polyhedra in the two polymorphs of $\mathrm{FeGm}_{3}\left(\mathrm{~B} 4-\mathrm{C}_{6} \mathrm{H}_{4} \mathrm{CHO}\right)_{2}$ were found in ${ }^{[7]}$ to be intermediate between a TP and a TAP $(\varphi=12.2$ and $18.8^{\circ}$ at the heights $h$ of these TP-TAP polyhedra of 2.36 and of $2.37 \AA$, respectively), while $C o N_{6}$-coordination polyhedron of an encapsulated cobalt(II) ion in the molecule
$\mathrm{CoGm}_{3}\left(\mathrm{~B} 4-\mathrm{C}_{6} \mathrm{H}_{4} \mathrm{CHO}\right)_{2}$ possesses an almost TP geometry $\left(\varphi=1.2^{\circ}\right.$ at $h=2.44 \AA$, Table 1$)$.

A caged iron(II) ion in the molecule $\mathrm{FeGm}_{3}(\mathrm{~B} 4-$ $\left.\mathrm{C}_{6} \mathrm{H}_{4} \mathrm{CHO}\right)_{2}$ was found in ${ }^{[7]}$ to be situated almost in the centre of its $\mathrm{FeN}_{6}$-coordination polyhedron, while the above cobalt(II) ion is shifted from the centre of $\mathrm{CoN}_{6}$-polyhedron in the direction of two of the three ribbed glyoximate chelate fragments due to the structural Jahn-Teller distortion of its low-spin electronic configuration $d^{7}$. Such low-spin state of the cobalt(II) clathrochelates can be stabilized by the crystal packing effects. ${ }^{[11-13]}$ In the crystal $\mathrm{CoGm}_{3}(\mathrm{~B} 4-$ $\left.\mathrm{C}_{6} \mathrm{H}_{4} \mathrm{CHO}\right)_{2} \cdot 0.5 \mathrm{CH}_{2} \mathrm{Cl}_{2}$, the observed $\pi . . . \pi$ stacking between $\mathrm{N}=\mathrm{C}-\mathrm{C}=\mathrm{N}$ chelate fragments of its neighboring macrobicyclic molecules, forming a clathrochelate dimer (Figure 3), cause the shortening of the corresponding coordination $\mathrm{Co}-\mathrm{N}$ bonds, while the third ribbed chelate fragment of these interacting macrobicyclic molecules of $\mathrm{CoGm}_{3}\left(\mathrm{~B} 4-\mathrm{C}_{6} \mathrm{H}_{4} \mathrm{CHO}\right)_{2}$, showing the greatest $\mathrm{Co}-\mathrm{N}$ distances, is not included in such bonding.

Acknowledgements. The authors gratefully acknowledge partial support of the RFBR (grants 14-03-00384 and 16-33-00146). NMR measurements of the paramagnetic cobalt(II) clathrochelate were supported by Russian Science Foundation (grant 14-13-00724).

\section{References and Notes}

1. Wise M.D., Holstein J.J., Pattison Ph., Besnard C., Solari E., Scopelliti R., Bricogne G., Severin K. Chem. Sci. 2015, 6, 1004-1010.

2. Jansze S.M., Cecot G., Wise M.D., Zhurov K.O., Ronson T.K., Castilla A.M., Finelli A., Pattison Ph., Solari E., Scopelliti R., 
Zelinskii G.E., Vologzhanina A.V., Voloshin Y.Z., Nitschke J.R., Severin K. J. Am. Chem. Soc. 2016, 138, 2046-2054.

3. Cecot G., Alameddine B., Prior S., De Zorzi R., Geremia S., Scopelliti R., Fadaei F.T., Solari E., Severin K. Chem. Commun. 2016, 52, 11243-11246.

4. Marmier M., Wise M.D., Holstein J.J., Pattison Ph., Schenk K., Solari E., Scopelliti R., Severin K. Inorg. Chem. 2016, 55, 4006-4015.

5. Marmier M., Cecot G., Vologzhanina A.V., Bila J.L., Zivkovic I., Ronnow H.M., Nafradi B., Solari E., Pattison Ph., Scopelliti R., Severin K. Dalton Trans. 2016, 45, 15507-15516.

6. Zhang Y.-Y., Lin Y.-J., Jin G.-X. Chem. Commun. 2014, 50, 2327-2329.

7. Zelinskii G.E., Chuprin A.S., Belov A.S., Novikov V.V., Vologzhanina A.V., Lebed E.G., Voloshin Y.Z. Inorg. Chim. Acta 2016, 453, 210-221.

8. Zhang J., Ma Z., Zhao H., Ge C., Wang Y., Zhang X. Inorg. Chem. Comm. 2016, 65, 63-67.

9. The reagents used, anhydrous $\mathrm{CoCl}_{2}, 4$-formylphenylboronic acid, sorbents and organic solvents were obtained commercially (Sigma-Aldrich). Glyoxime was obtained by condensation of glyoxal with hydroxylamine as described elsewhere. ${ }^{[14]}$ Analytical data (C, H, N contents) were obtained with a Carlo Erba model 1106 microanalyzer. MALDI-TOF mass spectrum was recorded without the matrix using a MALDITOF-MS Bruker Autoflex II (Bruker Daltonics) mass spectrometer in reflecto-mol mode. The ionization was induced by UV-laser with wavelength $337 \mathrm{~nm}$ and the sample was applied to a nickel plate. The accuracy of measurements was $0.1 \%$. ${ }^{1} \mathrm{H}$ NMR spectrum was recorded from DMSO- $d_{6}$ solution with a Bruker Avance 600 spectrometer. The measurements were done using the residual signal of DMSO- $d_{6}\left({ }^{1} \mathrm{H}\right.$ $2.50 \mathrm{ppm}) .{ }^{13} \mathrm{C}$ NMR spectrum could not be obtained due to paramagnetic broadening and poor solubility of the complex. IR spectrum of the solid sample ( $\mathrm{KBr}$ tablet) in the range of $400-4000 \mathrm{~cm}^{-1}$ was recorded with a Perkin Elmer FT-IR Spectrum BX II spectrometer.

$\mathrm{CoGm}_{3}\left(\mathrm{~B}_{4}-\mathrm{C}_{6} \mathrm{H}_{4} \mathrm{CHO}\right)_{2}$. Glyoxime $(0.32 \mathrm{~g}, 2.77 \mathrm{mmol})$, 4-formylphenylboronic acid $(0.29 \mathrm{~g}, 1.9 \mathrm{mmol})$ and $\mathrm{CoCl}_{2}$ $(0.16 \mathrm{~g}, 0.79 \mathrm{mmol})$ were dissolved/suspended in nitromethane $(15 \mathrm{~mL})$ with stirring under argon. The reaction mixture was refluxed under intensive stirring for $2 \mathrm{~h}$. Then the orange precipitate formed was filtered off, washed with water (15 mL, in three portions), ethanol (10 mL, in three portions), diethyl ether $(10 \mathrm{~mL}$, in three portions), hexane $(10 \mathrm{~mL}$, in three portions) and dried in vacuo. Yield: $0.238 \mathrm{~g}(62 \%)$. Anal. Calc. for $\mathrm{C}_{20} \mathrm{H}_{16} \mathrm{~B}_{2} \mathrm{CoN}_{6} \mathrm{O}_{8}(\%)$ : C, 43.76; H, 2.94; N, 15.31. Found (\%): C, 43.68; H, 2.87; N, 15.29. MS (MALDITOF) $\mathrm{m} / z$ (without matrix): $548[\mathrm{M}]^{+\bullet} .{ }^{1} \mathrm{H}$ NMR (DMSO- $d_{6}$ ) $\delta$ ppm: 6.59 (br.s, $4 \mathrm{H}, o-\mathrm{H}$ ), 7.29 (br.s, $4 \mathrm{H}, m-\mathrm{H}), 9.72$ (br.s, $2 \mathrm{H}, \mathrm{CHO}), 87.90$ (br.s, $6 \mathrm{H}, \mathrm{HC}=\mathrm{N})$. IR $(\mathrm{KBr}) \vee \mathrm{cm}^{-1}: 1559$ $v(\mathrm{C}=\mathrm{N}), 916,957 \mathrm{~m}, 1016,1145 v(\mathrm{~N}-\mathrm{O}), 1221 \mathrm{~m} v(\mathrm{~B}-\mathrm{O})$, $1689 v(\mathrm{C}=\mathrm{O})$.

$X$-Ray diffraction. The red-plate single crystal of the complex $\mathrm{C}_{20} \mathrm{H}_{16} \mathrm{~B}_{2} \mathrm{CoN}_{6} \mathrm{O}_{8} \cdot 0.5 \mathrm{CH}_{2} \mathrm{Cl}_{2} \quad(\mathrm{M}=591.40)$ is triclinic; at $100 \mathrm{~K}: \mathrm{a}=10.470(2), \mathrm{b}=11.100(2), \mathrm{c}=11.400(2)$ $\AA, \alpha=105.45(3), \beta=97.59(3), \gamma=112.78(3)^{\circ}, V=1135.4(5) \AA^{3}$, space group $P \overline{1}, \mathrm{Z}=2, \mathrm{D}_{\text {calcd. }}=1.730 \mathrm{~g} \cdot \mathrm{cm}^{-3}, \mu=2.152 \mathrm{~mm}^{-1}$. The intensities of 14770 reflections were collected from a single crystal with $0.13 \times 0.12 \times 0.04 \mathrm{~mm}$ dimensions at the K4.4 station of the Kurchatov Center for Synchrotron Radiation and Nanotechnology in Moscow (Russia) at a wavelength of $0.987 \AA$ using a MAR CCD 165 detector. Data collection was performed at $100 \mathrm{~K}$ using an Oxford CryoJet from Oxford Cryosystems Ltd. Data integration was carried out using the CCP4 software. A multi-scan empirical absorption correction was applied to the data using SCALA. The structure was solved by the direct method and refined by full-matrix least squares method against $\mathrm{F}^{2}$ of all data, using SHELXL-2014 ${ }^{[15]}$ and OLEX2 $2^{[16]}$ software. Non-hydrogen atoms were found on difference Fourier maps and refined with anisotropic displacement parameters with an exception of disordered carbon and oxygen atoms. The positions of hydrogen atoms were calculated and included in refinement in isotropic approximation by the riding model with the $\mathrm{U}_{\text {iso }}(\mathrm{H})=1.2 \mathrm{U}_{\mathrm{eq}}(\mathrm{C})$, where $\mathrm{U}_{\mathrm{eq}}(\mathrm{C})$ are equivalent thermal parameters of parent atoms. Crystallographic information file is available from the Cambridge Crystallographic Data Center upon request (https:// summary.ccdc.cam.ac.uk/structure-summary-form, deposition number 1411461).

DFT calculations. All calculations were carried out in ORCA package v. 3.0.3. ${ }^{[17]} \mathrm{X}$-Ray structure of the complex was used as an initial structure for geometry optimization. It was performed with non-hybrid PBE functional ${ }^{[18,19]}$ and using def2-TZVP basis sets. ${ }^{[20]}$ After geometry optimization tensors of hyperfine interactions for hydrogen and carbon nuclei were calculated using hybrid PBE0 functional ${ }^{[21]}$ and the same basis sets def2-TZVP, but with addition primitives with higher order of exponent to better description of electron density around a nucleus. Paramagnetic shifts for hydrogen and carbon nuclei were calculated by following equation: ${ }^{[22]}$

$$
\delta_{\text {par }}=\frac{S(S+1) \mu_{B}}{3 k T g_{N} \mu_{N}} \cdot g \cdot A^{T}
$$

10. Voloshin Y.Z., Kostromina N.A., Krämer R. Clathrochelates: Synthesis, Structure and Properties, Elsevier: Amsterdam, 2002. $432 \mathrm{p}$.

11. Novikov V.V., Ananyev I.V., Pavlov A.A., Fedin M.V., Lyssenko K.A., Voloshin Y.Z. J. Phys. Chem. Lett. 2014, 5, 496-500.

12. Vologzhanina A.V., Belov A.S., Novikov V.V., Dolganov A.V., Romanenko G.V., Ovcharenko V.I., Korlyukov A.A., Buzin M.I., Voloshin Y.Z. Inorg. Chem. 2015, 54, 5827-5838.

13. Pavlov A.A., Nelyubina Y.V., Kats S.V., Penkova L.V., Efimov N.N., Dmitrienko A.O., Vologzhanina A.V., Belov A.S., Voloshin Y.Z., Novikov V.V. J. Phys. Chem. Lett. 2016, 7, 4111-4116.

14. Park D.J., Stern A.G., Wilier R.L. Synth. Commun. 1990, 20, 2901-2906.

15. Sheldrick G.M. Acta Cryst. 2015, C71, 3-8.

16. Dolomanov O.V., Bourhis L.J., Gildea R.J., Howard J.A.K., Puschmann H. J. Appl. Cryst. 2009, 42, 339-341.

17. Neese F. ORCA. Version 3.0.3. Bonn, Germany: University of Bonn, 2013.

18. Perdew J.P., Burke K., Ernzerhof M. Phys. Rev. Lett. 1996 77, 3865-3868.

19. Perdew J.P., Burke K., Ernzerhof M. Phys. Rev. Lett. 1997, 78,1396

20. Weigend F., Ahlrichs R. Phys. Chem. Chem. Phys. 2005, 7, 3297.

21. Adamo C., Barone V. J. Chem. Phys. 1999, 110, 6158-6169.

22. Moon S., Patchkovskii S. Calculation of NMR and EPR Parameters. Theory and Applications (Kaupp M., Bühl M., Malkin V.G., Eds.). Weinheim, Germany: Wiley, 2004. 